\title{
Impact of residents' involvement in urological surgeries: a systematic review
}

\author{
Wedyan Salem Basaif ${ }^{1 *}$, Faisal Abdulaziz Almukhlifi ${ }^{2}$, Abdulhadi Turki Alsubaie ${ }^{1}$, \\ Ali Mohammed Alzarqa ${ }^{3}$, Ahmed Abdulsalam Alsaedi ${ }^{2}$, Bader Hamdi Binyousef ${ }^{4}$, \\ Awnallah Saud Alotaibi ${ }^{5}$, Ahmed Awad Mobaraki ${ }^{1}$, Abdulrahman Mohammed Alghamdi ${ }^{2}$, \\ Ahmad Aboukhshaba ${ }^{3}$, Tamer Mohammed Mahjari' ${ }^{1}$ Jehad Nabeel Qutub ${ }^{1}$
}

\author{
${ }^{1}$ Department Of Urology, King Fahad General Hospital, Jeddah, Saudi Arabia \\ ${ }^{2}$ Department Of Urology, Ohoud Hospital, Al Madinah, Saudi Arabia \\ ${ }^{3}$ Department Of Urology, King Abdulaziz Medical City, National Guard Hospital, Jeddah, Saudi Arabia \\ ${ }^{4}$ College Of Medicine, King Abdulaziz University, Jeddah, Saudi Arabia \\ ${ }^{5}$ Department Of Urology, King Fahad General Hospital, Al Madinah, Saudi Arabia
}

Received: 03 March 2021

Accepted: 19 March 2021

\section{*Correspondence:}

Dr. Wedyan Salem Basaif,

E-mail: wedyanbasaif@gmail.com

Copyright: (c) the author(s), publisher and licensee Medip Academy. This is an open-access article distributed under the terms of the Creative Commons Attribution Non-Commercial License, which permits unrestricted non-commercial use, distribution, and reproduction in any medium, provided the original work is properly cited.

\begin{abstract}
Many investigations have reported the impact of resident involvement in urological surgeries. We aimed to conduct this systematic review to create enough evidence regarding this impact based on the outcomes obtained from the relevant studies. We have performed both manual and electronic search through many databases like Google Scholar, Web of science, PubMed, Scopus, Cochrane library, the international standard randomised controlled trial number registry, and the world health organization virtual health library to obtain all the relevant citations. Our intended outcomes included the risk of developing complications, operative time, and rate of reoperations. We have included 17 studies that reported the impact of residents' involvement in urological surgical operations. while some studies reported some complications, the risk of developing complications was not significantly associated with residents' involvement according to most studies. Only one study reported that complications were significantly associated with residents' involvement. The rate of reoperation and readmission after the primary surgery was also non-significant. On the other hand, most of the included studies showed that residents' involvement was significantly associated with increased hospital stay and prolonged operative time. Our results indicate the residents' involvement does not impact the overall safety of the urological procedures and that this practice should be encouraged with adequate supervision.
\end{abstract}

Keywords: Urology, Residents, Impact, Involvement, Surgery

\section{INTRODUCTION}

Residents or doctors-in-training might face various challenges during the residency period which requires their integration in many surgical procedures that usually require various technical skills that these physicians might lack. Although many approaches have been proposed to teach surgical skills to residents, a hands-on approach would remain the most accurate way for better acquisition of the required skills. However, involving in these practices is essential to get enough experience with preservations regarding the minimum provided quality of care. Moreover, previous studies have demonstrated the employment of the graduated responsibility concept among these residents. ${ }^{1,2}$ It is essential to stress the need to provide acceptable rates of the provided care regarding patients' outcomes and satisfaction, which serves the residents, the patient, and the healthcare system. 
This would imply the increased need for supervision and working hours. ${ }^{3}$

Although the accreditation council for graduate medical education previously announced that residents or trainees within surgical departments are obliged to attend a specified number of surgical procedures to graduate, previous studies showed that the quantitative participation does not fulfill the required efficiency for these residents. $^{4-6}$ Moreover, training under supervision within the residency period to attain the required competence and skills is certainly better than performing without the needed experience and supervision. As a result of such issues, many concerns have aroused regarding the quality of these procedures and the quality of provided care. ${ }^{7,8}$ Consequently, many investigations have been previously published to encourage residency training on surgical procedures in many departments. ${ }^{9,10}$ Within urological surgeries, investigations have shown that residents' involvement was associated with a similar number of complications to senior urologists. However, the operative time was significantly prolonged among resident doctors. $^{8-12}$

There are many obstacles to be considered for the assessment of such involvement approaches. The challenges of the applied surgical techniques within the operations might add to the pre-existing burdens on the trainees due to the increasing technological advances which usually require the integration of fine skills. For instance, urology oncological procedures usually require minimally-invasive techniques. ${ }^{13,14}$ Operating open surgeries might also differ from surgeries with laparoscopic or robot-assessed techniques. However, investigations show that the outcomes for residents were similar to those obtained with senior surgeons. ${ }^{15,16}$ No previous systematic reviews have been published in this area. Consequently, we aimed to conduct this study to create enough evidence regarding the impact of residents' involvement in urological surgical procedures based on the outcomes obtained from the relevant studies.

\section{METHODS}

\section{Study population and inclusion criteria}

We conducted this systematic review to investigate the impact of residents' involvement in urological surgeries. Our outcomes included the clinically reported outcomes only, as the occurrence of complications and safety of patients, length of operational time and hospital stay, and rate of reoperations. Consequently, we have put strict criteria to include all the relevant studies and exclude all the irrelevant ones. Our inclusion criteria included 1) original studies, 2) reported the outcomes following a urological surgery by a resident, 3) human studies, 4) investigated any of the mentioned outcomes. On the other hand, we excluded articles if they 1) were not original, 2) was not done in the urological surgery department, was done in the urology department, but in combination with other departments (as pelvic prolapse or sacrocolpopexy, hernia, vaginal hysterectomy, and others), did not investigate the parameters of safety and efficacy related to the procedures as determined in our outcomes, or assistance was done, including robot-assessed surgeries, 3) investigated non-human subjects, 4) were incomplete or irrelevant outcomes, 5) were a thesis, protocol, letter, editorial, with non-available full-text. We prefer not to involve residents where assistance was introduced to assess the real efficacy of residents. For instance, studies have reported that supervision might reduce the rates of complications, while other studies have reported that robotic surgeries, which are usually big procedures, increased the operative time of the procedures, which, therefore, might bias the investigated outcomes, and therefore, such studies were excluded. ${ }^{17,18,20}$

\section{Search strategy}

Based on these criteria, we have extracted the relevant common key-words to retrieve all the relevant articles that can help us formulate the current literature. We have also used the MeSH database to attain all the possibly relevant words. The keywords included: resident, trainee, doctor-in-training, urology, urological surgery, urethral, urethroplasty, prostatectomy, and nephrectomy. Finally, these words were then formulated into a structured strategy that included all of them using the necessary boolean operators based on each searched database guidelines. These databases included Google Scholar, web of science, PubMed, Scopus, Cochrane Library, the international standard randomised controlled trial number registry, and world health organization virtual health library. In addition to this electronic-based approach, we searched the references of the included studies and relevant reviews to include all the articles that were potentially missed by the main electronic strategy. In all of these steps and the following ones, we followed the preferred reporting items for systematic reviews and meta-analyses (PRISMA) guidelines. ${ }^{21}$

\section{Screening, data extraction}

Following the thorough search strategy that we conducted, both electronically and manually, we created an endnote library, to which we have retrieved all the search results to detect all the duplicates. In the following steps, we used our criteria to screen the remaining references which were grouped into a unified sheet, in order not to miss any articles and to make the process easy on members. Each members' screening and extraction results were blinded to miss any bias regarding the study selection and to properly include all the relevant studies only. We conducted two approaches to screening. These include the title and abstract screening followed by full-text screening. After agreement on the selected articles, two members volunteered to design a suitable extraction sheet to collect the relevant information from the included studies. These were 1) baseline characteristics as study design, reference, gender, title, 
year, country, and last name of the first author, 2) outcomes as the length of operation, complications, overall efficacy, length of hospital stay, and reoperation or readmission, 3) risk of bias assessment.

\section{Assessment of bias}

This was the last step of the extraction sheet and was done using the adjusted Newcastle-Ottawa scale (NOS) for cross-sectional studies was used. ${ }^{22}$ The tool included three main domains including methodological quality, compatibility, and outcomes. According to the grading system of the tool (0-10), all studies were to be marked as non-satisfactory (0-4), satisfactory (5-6), good (7-8), and excellent (9-10) based on their degree of assessed bias.

\section{Included studies}

After the online database searching of the aforementioned databases, we identified 5474 citations that could be relevant to our aimed outcomes. Another two citations were also identified by the process of manual search and were added to the combined endnote library to exclude all the duplicates. Title and abstract screening were done for 1920 citations, by which we identified 197 articles for full-text screening. Finally, we included 17 articles. These were done according to our previously discussed inclusion and exclusion criteria and our announced outcomes. The detailed information of the search strategy can be seen in Figure 1.

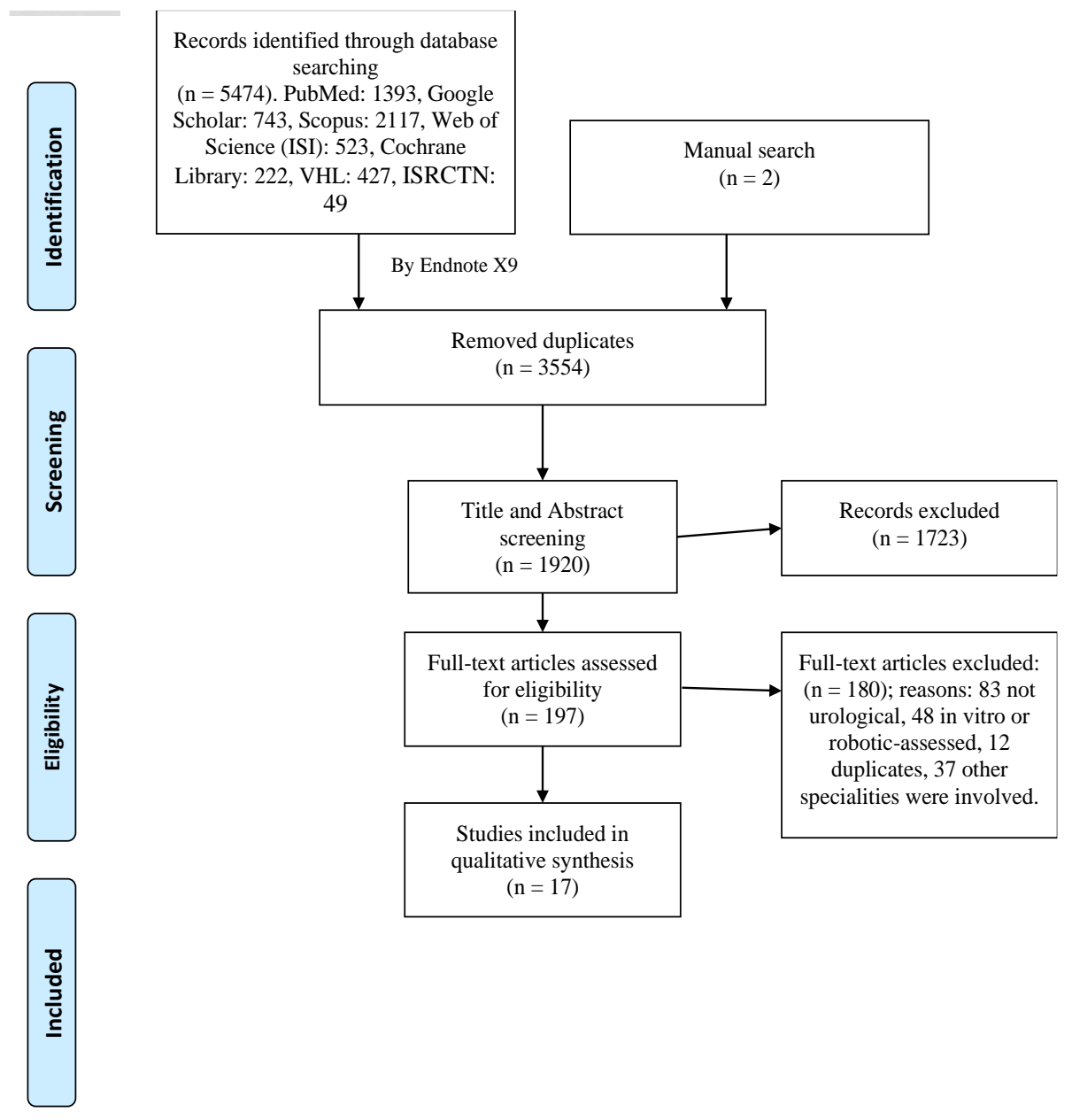

\section{RESULTS}

Figure 1: The flow chart for search strategy, including selected studies identification process.

\section{Assessed risk of bias}

According to the NOS scale, most of the included studies were marked good while the rest of them were satisfactory with only one marked excellent. This means that the included studies did not have a significant bias. Bias per assessed domains was variable for each one and not one of the domains showed the highest risk of bias across the different studies. The detailed assessment and grading of all the included studies can be seen in Table 1 .

\section{Baseline characteristics}

We have finally included 17 studies that were conducted between 2005 and 2020. Most of the studies were conducted from data within the United States, which is attributable to the involvement of the national surgical quality improvement program's (NSQIP) as most studies depended on the retrospective data collection from this database. The total number of patients is 110,690 with huge variability between the included studies. Other baseline characteristics and a summary of the outcomes are presented in Table 2 . 
Table 1: Risk of bias assessment of the included studies using the modified modified Newcastle-Ottawa quality assessment scale.

\begin{tabular}{|c|c|c|c|c|c|c|c|c|c|c|}
\hline & & Selection & & & & Comparability & Outcome & & & \\
\hline Author & Year & $\begin{array}{l}\text { Representativeness } \\
\text { of the sample }\end{array}$ & $\begin{array}{l}\text { Sample } \\
\text { size }\end{array}$ & $\begin{array}{l}\text { Non- } \\
\text { Respondents }\end{array}$ & $\begin{array}{l}\text { Ascertainment } \\
\text { of the Exposure }\end{array}$ & $\begin{array}{l}\text { The Subjects } \\
\text { in Different } \\
\text { Outcome } \\
\text { Groups are } \\
\text { Comparable }\end{array}$ & $\begin{array}{l}\text { Assessment } \\
\text { of outcome }\end{array}$ & $\begin{array}{l}\text { Statistical } \\
\text { analysis }\end{array}$ & $\begin{array}{l}\text { Total } \\
\text { score }\end{array}$ & Quality \\
\hline Aisen et al & 2018 & + & + & & + & + & + & + & 6 & Satisfactory \\
\hline Allard et al & 2015 & + & + & + & + & ++ & + & + & 8 & Good \\
\hline $\begin{array}{l}\text { Del Rosso } \\
\text { et al }\end{array}$ & 2013 & + & + & + & + & ++ & + & + & 8 & Good \\
\hline Herrick et al & 2013 & + & + & + & + & + & + & + & 7 & Good \\
\hline $\begin{array}{l}\text { Holland et } \\
\text { al }\end{array}$ & 2019 & + & + & & + & + & + & + & 6 & Satisfactory \\
\hline Kara et al & 2018 & + & + & + & & + & + & + & 6 & Satisfactory \\
\hline Kern et al & 2014 & + & + & + & ++ & + & + & + & 8 & Good \\
\hline Ku et al & 2008 & + & + & + & + & + & + & & 6 & Satisfactory \\
\hline $\begin{array}{l}\text { Loppenberg } \\
\text { et al }\end{array}$ & 2016 & + & + & + & + & ++ & + & + & 8 & Good \\
\hline $\begin{array}{l}\text { Matulewicz } \\
\text { et al }\end{array}$ & 2014 & + & + & + & ++ & ++ & + & + & 9 & Excellent \\
\hline Meyer et al & 2015 & + & + & + & + & + & + & + & 7 & Good \\
\hline Nguyen et al & 2008 & + & + & & + & + & + & & 5 & Satisfactory \\
\hline Nieder et al & 2005 & + & & + & + & & + & + & 5 & Satisfactory \\
\hline Prive et al & 2019 & + & + & + & + & ++ & + & + & 8 & Good \\
\hline $\begin{array}{l}\text { Roghmann } \\
\text { et al }\end{array}$ & 2013 & + & + & + & + & + & + & + & 7 & Good \\
\hline $\begin{array}{l}\text { Vetterlein et } \\
\text { al }\end{array}$ & 2016 & + & + & & + & ++ & + & + & 7 & Good \\
\hline Yip et al & 2020 & + & + & + & + & ++ & + & + & 8 & Good \\
\hline
\end{tabular}


Basaif WS et al. Int J Community Med Public Health. 2021 Apr;8(4):2012-2019

Table 2: A summary of the baseline characteristics and outcomes of the included studies.

\begin{tabular}{|c|c|c|c|c|c|c|c|c|c|c|}
\hline \multirow[b]{2}{*}{ Reference } & \multirow[b]{2}{*}{ Year } & \multirow[b]{2}{*}{ Country } & \multirow[b]{2}{*}{$\begin{array}{l}\text { Study } \\
\text { design }\end{array}$} & \multirow[b]{2}{*}{ Data collection } & \multirow[b]{2}{*}{ Sample size } & \multirow[b]{2}{*}{ Male (n) } & \multirow[b]{2}{*}{$\begin{array}{l}\text { Mean age } \\
\text { (SD) }\end{array}$} & \multicolumn{3}{|l|}{ Outcomes } \\
\hline & & & & & & & & Complications & $\begin{array}{l}\text { Operative } \\
\text { time }\end{array}$ & Re-operation \\
\hline Aisen et al $^{33}$ & 2018 & $\begin{array}{l}\text { United } \\
\text { States }\end{array}$ & $\begin{array}{l}\text { Cross- } \\
\text { sectional }\end{array}$ & Retrospective & 29,488 & - & - & Increased & Longer & NS \\
\hline Allard et $a^{28}$ & 2015 & $\begin{array}{l}\text { United } \\
\text { States }\end{array}$ & $\begin{array}{l}\text { Cross- } \\
\text { sectional }\end{array}$ & Retrospective & 8152 & 5093 & & NS & Longer & NS \\
\hline $\begin{array}{l}\text { Del Rosso } \\
\text { et } \mathbf{a l}^{29}\end{array}$ & 2013 & Italy & $\begin{array}{l}\text { Cross- } \\
\text { sectional }\end{array}$ & Prospective & 80 & 80 & $\begin{array}{l}66.3 \\
(51-78)\end{array}$ & Ns & NS & NS \\
\hline $\begin{array}{l}\text { Herrick } \\
\text { et } \mathbf{~ a l}^{30}\end{array}$ & 2013 & Lebanon & $\begin{array}{l}\text { Cross- } \\
\text { sectional }\end{array}$ & Prospective & 79 & 79 & $64.6(9.3)$ & NS & Longer & NS \\
\hline $\begin{array}{l}\text { Holland } \\
\text { et } \mathbf{a l}^{32}\end{array}$ & 2019 & $\begin{array}{l}\text { United } \\
\text { States }\end{array}$ & $\begin{array}{l}\text { Cross- } \\
\text { sectional }\end{array}$ & Retrospective & 3316 & - & - & NS & Longer & Lower \\
\hline Kara et al & 2018 & $\begin{array}{l}\text { United } \\
\text { States }\end{array}$ & $\begin{array}{l}\text { Cross- } \\
\text { sectional }\end{array}$ & Prospective & 309 & 309 & 64.2 & NS & NS & NS \\
\hline Kern et $a^{34}$ & 2014 & $\begin{array}{l}\text { United } \\
\text { States }\end{array}$ & $\begin{array}{l}\text { Cross- } \\
\text { sectional }\end{array}$ & Retrospective & 1251 & 752 & - & NS & Longer & NS \\
\hline $\mathbf{K u}$ et $\mathbf{a l}^{31}$ & 2008 & $\begin{array}{l}\text { United } \\
\text { States }\end{array}$ & $\begin{array}{l}\text { Cross- } \\
\text { sectional }\end{array}$ & Retrospective & 5,070 & 5,070 & $60.7(6.6$ & NS & Longer & NS \\
\hline $\begin{array}{l}\text { Loppenberg } \\
\text { et } \mathbf{a l}^{35}\end{array}$ & 2016 & $\begin{array}{l}\text { United } \\
\text { States }\end{array}$ & $\begin{array}{l}\text { Cross- } \\
\text { sectional }\end{array}$ & Retrospective & 1,378 & - & $58(48-68)$ & NS & Longer & NS \\
\hline $\begin{array}{l}\text { Matulewicz } \\
\text { et } \mathbf{a l}^{23}\end{array}$ & 2014 & $\begin{array}{l}\text { United } \\
\text { States }\end{array}$ & $\begin{array}{l}\text { Cross- } \\
\text { sectional }\end{array}$ & Retrospective & 40,000 & 31,031 & 64 & NS & Longer & Lower \\
\hline Meyer et $\mathrm{al}^{24}$ & 2015 & $\begin{array}{l}\text { United } \\
\text { States }\end{array}$ & $\begin{array}{l}\text { Cross- } \\
\text { sectional }\end{array}$ & Retrospective & 235 & 235 & $51(43-66)$ & NS & Longer & NS \\
\hline $\begin{array}{l}\text { Nguyen } \\
\text { et } \mathbf{a l}^{36}\end{array}$ & 2008 & $\begin{array}{l}\text { United } \\
\text { States }\end{array}$ & $\begin{array}{l}\text { Cross- } \\
\text { sectional }\end{array}$ & Prospective & 267 & 267 & $39.1(6.4)$ & NS* & NS & NS \\
\hline $\begin{array}{l}\text { Nieder } \\
\text { et } \mathbf{a l}^{37}\end{array}$ & 2005 & $\begin{array}{l}\text { United } \\
\text { States }\end{array}$ & $\begin{array}{l}\text { Cross- } \\
\text { sectional }\end{array}$ & Prospective & 173 & - & 67 & Decreased & NS & NS \\
\hline Prive et al $^{27}$ & 2019 & Netherlands & $\begin{array}{l}\text { Cross- } \\
\text { sectional }\end{array}$ & Retrospective & 229 & 229 & - & NS & Longer & NS \\
\hline $\begin{array}{l}\text { Roghmann } \\
\text { et } \text { al }^{17}\end{array}$ & 2013 & $\begin{array}{l}\text { United } \\
\text { States }\end{array}$ & $\begin{array}{l}\text { Cross- } \\
\text { sectional }\end{array}$ & Retrospective & 19462 & - & - & NS & NS & NS \\
\hline $\begin{array}{l}\text { Vetterlein } \\
\text { et } \mathbf{a l}^{25}\end{array}$ & 2016 & $\begin{array}{l}\text { United } \\
\text { States }\end{array}$ & $\begin{array}{l}\text { Cross- } \\
\text { sectional }\end{array}$ & Retrospective & 267 & 267 & $37(27-46)$ & NS & Longer & NS \\
\hline Yip et $\mathbf{a l}^{26}$ & 2020 & $\begin{array}{l}\text { United } \\
\text { States }\end{array}$ & $\begin{array}{l}\text { Cross- } \\
\text { sectional }\end{array}$ & Retrospective & 934 & 934 & 48 (17) & NS & Longer & NS \\
\hline
\end{tabular}

NS: non-significant or was not estimated. All outcomes were investigated for a possible risk-association with residents' involvement. *assessed the visual pain score (VAS). 


\section{DISCUSSION}

In the present study, we aimed to elaborate on the impact of residents' involvement in urological surgeries as assessed by clinical variables including risk of occurrence of complications, the operative time, and the risk of reoccurrence from investigations that previously compared between residents and non-resident populations.

\section{The risk to develop complications}

This outcome was extensively reported in our study and is considered the hallmark for assessment of the overall safety of patients and the quality of provided care. In 2014, a large cohort study by Matulewicz et al. ${ }^{23}$ included 40,000 patients from the 2005-2011 NSQIP that were divided into patients that underwent urological surgeries by residents and non-residents doctors. The authors reported that the occurrence of overall complications was not significantly associated with residents. However, some complications were significantly associated with this population as surgical complications, the occurrence of sepsis, and septic shock. However, the authors reported that the presence of residents was associated with decreased risk of developing complications and overall mortality. Based on the NSQIP data also, Meyer et a, Vetterlein et al and Yip et al investigated similar outcomes in patients that underwent one-stage anterior urethroplasties, orchiectomy, minimally-invasive, and male infertility procedures, respectively. ${ }^{24-26}$ They reported that the presence of residents was not a significant predictor for the occurrence of adverse events and complications. This was also supported by Privé et al, Allard et al and Del Rosso et al that reported that although residents induced some complications, these were managed intraoperatively. ${ }^{27-29}$

The safety of residents' performance was furtherly indicated by Benjamin et al that reported that the presence of residents in laser prostate surgeries is not associated with significant rates of complications. ${ }^{30}$ In the study by $\mathrm{Ku}$ et al, which assessed the performance during radical prostatectomy in 5,736 patients, they reported that residents' presence was not significantly associated with the presence of complications or the need to perform a blood transfusion. ${ }^{31}$ In 2019, Holland et al reported that the rate of complications was higher in the resident group, but not significant. $^{32}$ Moreover, the involvement of residents in inpatient care significantly decreased the rate of complications. Aisen et al found significantly high rates of complications in the resident's group, although they performed on younger patients and with significantly higher rates of comorbidities than the group that did not comprise residents' involvement. ${ }^{33}$ Kern et al also reported that the presence of residents and fellows was a significant predictor for overall and serious complications in minimally-invasive and nephrectomy procedures. ${ }^{34}$ In hydrocele repair surgeries, residents' involvement was not a risk for and was not associated with developing complications. ${ }^{35}$ During vasectomy operation, Nguyen et al assessed the rates of complications and pain by the visual analog score (VAS) between residents and senior urologists. ${ }^{36}$ Although the rate of complications and mean VAS score were higher in the residents' group, the difference was not significant. A previous study by Nieder et al reported that the rate of complications after transurethral bladder tumor resection, the rate of complications was $5.8 \%$ for both fellow and resident trainees under supervision. ${ }^{37}$ However, the authors reported that the rates of complications and bladder perforation could be more frequent with senior urologists than trainees, however, no statistical analysis was done. Moreover, McAbee et al reported that the rate of infection was $0.3 \%$ only following penile prosthesis placement surgeries. $^{38}$

\section{Impact on the rates of reoperation}

In the study by Matulewicz et al, the presence of residents was associated with significantly lower rates of reoperations as compared to the non-residents' population which was also supported by Holland et al, and Allard et al on the other hand, Meyer et al reported that none of the patients were readmitted for reoperation in their study, which was also reported by Löppenberg et al, although attendant students had some rates of reoperation and readmission, but with no significance. ${ }^{23,24,28,32,35}$ Moreover, Benjamin et al reported that reoperations were not significantly associated with residents' performance in a 6-month follow-up period. This was also reported by $\mathrm{Ku}$ et al, and Yip et al. ${ }^{26,30,31}$

\section{Impact on the operative time}

Matulewicz et al reported that the residents' population had significantly higher operative times and hospital stays, which is also reported by Kern et al, Aisen et al, Allard et al, Yip et al. ${ }^{23,24,26,33,34}$ Although the presence of residents was significantly associated with increased operative time in the performed surgeries, the length of hospital stay was not significantly different from the nonresident group, in the studies by Meyer et al, and Vetterlein et al, Benjamin et al, and Privé et al reported that longer operative time was associated with the residents' group, however, no complications were significantly noticed. ${ }^{24,25,27,30}$ Interestingly, $\mathrm{Ku}$ et al reported that patients that underwent surgeries by residents did not significantly stay in hospitals for longer periods although the operative time was significantly prolonged in these patients. ${ }^{31}$ Longer operative time was also reported by Holland et $\mathrm{al}^{32}$. Löppenberg et al. ${ }^{35}$ reported that both residents and post-graduate students had an increased risk of prolonged operative time.

These results suggest that residents' involvement does not significantly affect the safety of the patients undergoing urological procedures, despite not being time efficacious. Our results are also consistent with previous studies from other medical departments. A previous meta-analysis by Boughie et al showed that residents' involvement in obstetrics and gynecology surgeries was not significantly 
associated with the development of complications but with prolonged operative periods and risk of performing frequent blood transfusions. ${ }^{39}$ On the other hand, residents' involvement in high-risk operations might increase the risk of mistakes and increase the rates of complications and hospital stay, and therefore, high-risk operations should be subjected to strict supervision to minimize the possible mistakes and obtain the best outcomes. ${ }^{40}$ It is also worth mentioning that, although the presence of video and supervision assistance might add to the efficacy of the performing residents, Pycha et al still reported that the rate of complications was high (16\%) for these residents. ${ }^{17,29,41}$ However, such studies were excluded as previously discussed to obtain better nonbiased evidence regarding the overall safety and efficacy of residents alone.

The absence of randomization in the included studies might be a limitation to our study. Moreover, many studies were conducted on a retrospective basis and not all studies have reported the detailed outcomes that may result secondary to the residents' involvement. Although the evidence in our study might be strong enough due to the number of included studies and the absence of significant heterogeneity, we recommend that randomized studies should be conducted for better validation of the evidence.

\section{CONCLUSION}

Our results encourage the practices of residents' involvement in urological surgical procedures to obtain the required experience. Our recommendations are built on the obtained evidence from the included studies which showed that residents' involvement is not associated with significant reoperations, complications, and adverse events. The main issue would represent the longer operative time consumed by residents; however, this would be the cost for a better quality of care and an excellent experience for these residents.

Funding: No funding sources

Conflict of interest: None declared

Ethical approval: Not required

\section{REFERENCES}

1. Schnapp BH, Caretta-Weyer HA, Cortez E. Curated Collections for Clinician Educators: Five Key Papers on Graduated Responsibility in Residency Education. Cureus. 2019;11(4):e4383.

2. Teman NR, Gauger PG, Mullan PB, Tarpley JL, Minter RM. Entrustment of general surgery residents in the operating room: factors contributing to provision of resident autonomy. J Am Coll Surg. 2014;219(4):778-87.

3. Curet MJ. Resident work hour restrictions: where are we now? J Am Coll Surg. 2008;207(5):767-76.

4. Education ACfGM. Common Program Requirements. 2019; https://www.acgme.org/What-
We-Do/Accreditation/Common-Program-

Requirements. Accessed February 20, 2021.

5. Elfenbein DM. Confidence crisis among general surgery residents: a systematic review and qualitative discourse analysis. JAMA surgery. 2016;151(12):1166-75.

6. Coleman JJ, Esposito TJ, Rozycki GS, Feliciano DV. Early Subspecialization and Perceived Competence in Surgical Training: Are Residents Ready? J Am College Surg. 2013;216(4):764-71.

7. Rosen GH, Murray KS, Greene KL, Pruthi RS, Richstone L, Mirza M. Effect of COVID-19 on urology residency training: a nationwide survey of program directors by the Society of Academic Urologists. The J Urol. 2020;204(5):1039-45.

8. Matulewicz RS, Pilecki M, Rambachan A, Kim JYS, Kundu SD. Impact of Resident Involvement on Urological Surgery Outcomes: An Analysis of 40,000 Patients from the ACS NSQIP Database. J Urol. 2014;192(3):885-90.

9. Allard CB, Meyer CP, Gandaglia G. The Effect of Resident Involvement on Perioperative Outcomes in Transurethral Urologic Surgeries. J Surg Education. 2015;72(5):1018-25.

10. Lim S, Parsa AT, Kim BD, Rosenow JM, Kim JY. Impact of resident involvement in neurosurgery: an analysis of 8748 patients from the 2011 American College of Surgeons National Surgical Quality Improvement Program database. J neurosur. 2015;122(4):962-70.

11. Meyer CP, Hanske J, Friedlander DF. The Impact of Resident Involvement in Male One-stage Anterior Urethroplasties. Urology. 2015;85(4):937-41.

12. Löppenberg B, Cheng PJ, Speed JM. The Effect of Resident Involvement on Surgical Outcomes for Common Urologic Procedures: A Case Study of Uniand Bilateral Hydrocele Repair. Urology. 2016;94:70-6.

13. Ruhotina N, Dagenais J, Gandaglia G, et al. The impact of resident involvement in minimallyinvasive urologic oncology procedures. Canad Urological Asso j. 2014;8(9-10):334-40.

14. Duchene DA, Rosso F, Clayman R. Current minimally invasive practice patterns among postgraduate urologists. J Endourol. 1797;25:2011.

15. Schommer E, Tonkovich K, Li Z, Thiel DD. Impact of Resident Involvement on Robot-Assisted Radical Prostatectomy Outcomes. J Endourol. 2016;30(10):1126-31.

16. Lee Z, Lightfoot AJ, Mucksavage P, Lee DI. Can robot-assisted radical prostatectomy be taught to chief residents and fellows without affecting operative outcomes? Prostate Int. 2015;3(2):47-50.

17. Roghmann F, Ravi P, Hanske J. Perioperative outcomes after radical cystectomy at NCI-designated centres: Are they any better? Canad Urological Association j. 2015;9(5-6):207-12.

18. McMillan DT, Viera AJ, Matthews J. Resident involvement and experience do not affect 
perioperative complications following robotic prostatectomy. World urol. 2015;33(6):793-9.

19. Baber J, Staff I, McLaughlin T. Impact of Urology Resident Involvement on intraoperative, Long-Term Oncologic and Functional Outcomes of Robotic Assisted Laparoscopic Radical Prostatectomy. Urology. 2019;132:43-8.

20. Schommer E, Tonkovich K, Li Z, Thiel DD. Impact of Resident Involvement on Robot-Assisted Radical Prostatectomy Outcomes. J Endourol. 2016;30(10):1126-31.

21. Liberati A, Altman DG, Tetzlaff J. The PRISMA statement for reporting systematic reviews and metaanalyses of studies that evaluate healthcare interventions: explanation and elaboration. BMJ. 2009;339:b2700.

22. Matulewicz RS, Pilecki M, Rambachan A, Kim JY, Kundu SD. Newcastle- Ottawa: Quality assessment scale adapted for cross-sectional studies. Impact of resident involvement on urological surgery outcomes: an analysis of 40,000 patients from the ACS NSQIP database. J Urol. 2014;192(3):885-90.

23. Meyer CP, Hanske J, Friedlander DF. The impact of resident involvement in male one-stage anterior urethroplasties. Urology. 2015;85(4):937-41.

24. Vetterlein MW, Seisen T, Löppenberg B. Resident Involvement in Radical Inguinal Orchiectomy for Testicular Cancer Does Not Adversely Impact Perioperative Outcomes-A Retrospective Study. Urologia int. 2017;98(4):472-7.

25. Yip W, Vij SC, Li J, Samplaski MK. The effect of trainee involvement on surgical outcomes and complications of male infertility surgical procedures. Andrologia. 2020;52(9):e13719.

26. Privé B, Kortleve M, van Basten JP. Evaluating the impact of resident involvement during the laparoscopic nephrectomy. Central Eur j urol. 2019;72(4):369-73.

27. Allard CB, Meyer CP, Gandaglia G. The Effect of Resident Involvement on Perioperative Outcomes in Transurethral Urologic Surgeries. J Surg Educ. 2015;72(5):1018-25.

28. Del Rosso A, Masciovecchio S, Paradiso Galatioto G, Vicentini C. Resident training in urology: bipolar transurethral resection of the prostate - a safe method in learning endoscopic surgical procedure. Archivio italiano di urologia, andrologia. 2013;85(2):78-81.

29. Herrick BW, Yap RL. It is safe to teach residents laser prostate surgery in the private practice setting. Urology. 2013;81(3):629-32.

30. Ku TS, Kane CJ, Sen S, Henderson WG, Dudley RA, Cason BA. Effects of hospital procedure volume and resident training on clinical outcomes and resource use in radical retropubic prostatectomy surgery in the
Department of Veterans Affairs. J Urol. 2008;179(1):272-8.

31. Holland BC, Patel N, Sulaver R. Resident Impact on Patient \& Surgeon Satisfaction and Outcomes: Evidence for Health System Support for Urology Education. Urology. 2019;132:49-55.

32. Aisen CM, James M, Chung DE. The Impact of Teaching on Fundamental General Urologic Procedures: Do Residents Help or Hurt? Urology. 2018;121:44-50.

33. Kern SQ, Lustik MB, McMann LP, Thibault GP, Sterbis JR. Comparison of outcomes after minimally invasive versus open partial nephrectomy with respect to trainee involvement utilizing the American College of Surgeons National Surgical Quality Improvement Program. J Endourol. 2014;28(1):40-7.

34. Löppenberg B, Cheng PJ, Speed JM. The Effect of Resident Involvement on Surgical Outcomes for Common Urologic Procedures: A Case Study of Uniand Bilateral Hydrocele Repair. Urology. 2016;94:70-6.

35. Nguyen CT, Hernandez AV, Gao T, Thomas AA, Jones JS. Office based vasectomy can be performed by supervised urological residents with patient pain and morbidity comparable to those of a staff surgeon procedure. J Urol. 2008;180(4):1451-4.

36. Nieder AM, Meinbach DS, Kim SS, Soloway MS. Transurethral bladder tumor resection: intraoperative and postoperative complications in a residency setting. J Urol. 2005;174(6):2307-9.

37. McAbee KE, Pearlman AM, Terlecki RP. Infection following penile prosthesis placement at an academic training center remains low despite involvement of surgeons-in-training. Investigative clin urol. 2018;59(5):342-7.

38. Bougie O, Zuckerman SL, Switzer N, How J, Sey M. Influence of Resident Involvement in Obstetrics and Gynaecology Surgery on Surgical Outcomes: Systematic Review and Meta-Analysis. J obstetr gynaecol Canad. 2018;40(9):1170-7.

39. Baisiwala S, Shlobin NA, Cloney MB, Dahdaleh NS. Impact of Resident Participation During Surgery on Neurosurgical Outcomes: A Meta-Analysis. World neurosurgery. 2020;142:1-12.

40. Pycha A, Lodde M, Lusuardi L. Teaching transurethral resection of the bladder: still a challenge? Urology. 2003;62(1):46-8.

Cite this article as: Basaif WS, Almukhlifi FA, Alsubaie AT, Alzarqa AM, Alsaedi AA, Binyousef $\mathrm{BH}$, et al. Impact of residents' involvement in urological surgeries: a systematic review. Int J Community Med Public Health 2021;8:2012-9. 